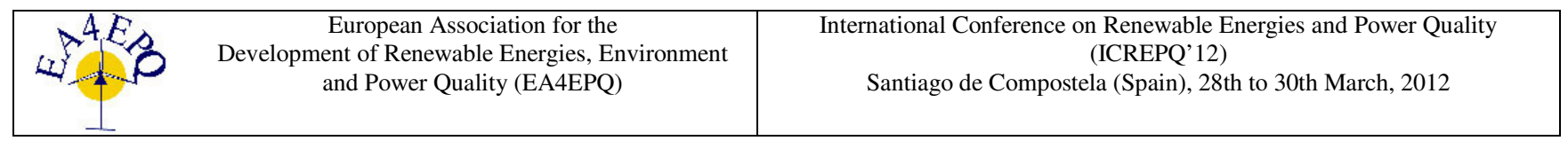

\title{
Viability Study for Use of Rice Husk in Electricity Generation by Biomass
}

\author{
M. O. Oliveira ${ }^{2-3}$, J. M. Neto ${ }^{1}$, M. C. Inocencio ${ }^{1}$, O. H. Ando Junior ${ }^{1}$, A. S. Bretas ${ }^{2}$ and O. E. Perrone ${ }^{3}$ \\ ${ }^{\mathbf{1}}$ Electrical Engineering Department \\ SATC, Beneficent Association of Santa Catarina Coal Industry \\ 73 Pascoal Meller Street, Criciúma-Sc (Brazil) \\ Phone/Fax number: +55 48 3431-75.50, e-mail: joao.neto@satc.edu.br, marcel.inocencio@satc.edu.br \\ oswaldo.junior@satc.edu.br \\ ${ }^{2}$ Electrical Engineering Department \\ UFRGS, Federal University of Rio Grande do Sul \\ 103 Osvaldo Aranha Avenue, Porto Alegre-Rs (Brazil) \\ Phone/Fax number: +55 51 3308-31.29, e-mail: moliveira@ece.ufrgs.br, abretas@ece.ufrgs.br \\ ${ }^{3}$ Energy Study Center to Development -CEED \\ UNaM, National University of Misiones \\ 327 Juan Manuel de Rosas Street, Oberá, Mnes. (Argentina) \\ Phone/Fax number: +54 03755-422170, e-mails: oliveira@fio.unam.edu.ar, perrone@fio.unam.edu.ar
}

\begin{abstract}
This paper presents the main technical and economic issues related to the study of a rice husk small-scale thermal power generation from a Southern Brazilian Rice Processing Cooperative Agriculture. In this study, a case study energy cogeneration associated with rice processing is presented with the estimated cost of operation and maintenance of a small pilot plant. It is also considered the impact of carbon credits sale inflow funds, which can reduce production costs related to electricity consumption. It will be presented also that the possibility of selling carbon credits, increases the project economic viability by $50 \%$, allowing a reduction in the investment return time by $20 \%$.
\end{abstract}

\section{Key words}

Alternative energy sources, electricity, rice husk, viability analysis, environmental impact.

\section{Introduction}

The discussion of the impacts caused by reliance on fossil fuels contributes to global concern for sustainable solutions in the generation of electricity using clean and renewable sources. For many years the advantages, disadvantages and technical difficulties that other primary sources (wind, solar, tidal, etc.) have when applied to the commercial electricity production have been discussed.

A substitute for fossil fuels to generate electricity has been biomass, which is a renewable energy source, and has contributed to reducing emissions of greenhouse effect gases. However, it should be understood that for the efficient use of biomass in thermal generation, a technology assessment should be realized, together with an economic and financial analysis along with a detailed study on the environmental impact of the activities involved.

The South of Brazil is characterized by being an agricultural region with a high level of food production, emphasizing mainly the production of grains (rice, soy, corn). In this sense, substantial quantities of agricultural wastes (with the potential for electricity generation) are produced, highlighting the rice husk. Where it is generated, rice processing industries, the bark is applied to the drying of grain and parboiling. Moreover, also used in industries that are generating with synchronous motors with reciprocating piston beyond the recent thermoelectric, using steam turbine (Rankine cycle) whose viability is proven [1].

According to 2008 data from IBGE (Brazilian Institute of Geography and Statistics), the states of Rio Grande do Sul and Santa Catarina have a production of paddy, of 8.3 million tons per year [t/year]. It is also known that $22 \%$ of the gross weight of the grain, after processing, results in the shell which has a good potential for energy conversion, having a lower calorific value of 13.4 MJ / $\mathrm{kg}$ [2].

However, the viability of installing a micro power station (MPS) in the processing industries should be evaluated, serving as a tool for decision making deployment. Thus, the inflow of funds from the sale of carbon credits obtained by this type of project, certainly positively affects the economic viability of the enterprise, so as to contribute to the appropriate destination for the rice husk. 


\section{Case Study: Cogeneration Associated with the Processing of Rice}

The study presented in this paper was developed in a processing company with a storage capacity of more than 3 million bags of rice, receiving average 83,000 tons per year. This volume generates around 18,300 tons of rice husk per year. To this total, is added 3,000 tons of dirt from the resulting process of cleaning the grain.

A factor of $15 \%$ for the total yielded from the process of electricity generation a year through the burning of the rice husk is used in this study [3].

Knowing the volume of biomass that is burned in the boiler, one can measure the potential for electricity to be generated by the following equation:

$$
E G=\frac{M \cdot P C I \cdot \eta}{860}
$$

where:

$\mathrm{EG}=$ energy generated per year [MWh/year]

$\mathrm{LHV}=$ net Calorific Value $[\mathrm{Kcal} / \mathrm{Kg}]$

$\mathrm{M}=$ amount of bark in Tons

$\eta=$ efficiency of the process

Applying the equation developed in [3], and adopting as the rice husk calorific value of $3,200 \mathrm{kcal} / \mathrm{kg}$ as measured in [4], results in a potential power generation of 11,890 MWh/year, which meets the energy demand of the cooperative over the years, as shown in Table I.

Table I. - Electrics characteristic of company studied

\begin{tabular}{|l|c|c|c|c|}
\hline Months/08 & $\begin{array}{c}\text { Consumption } \\
\text { special time } \\
{[\mathbf{k W h}]}\end{array}$ & $\begin{array}{c}\text { Consumption } \\
\text { common } \\
\text { time }[\mathbf{k W h}]\end{array}$ & $\begin{array}{c}\text { Demand } \\
{[\mathbf{k W}]}\end{array}$ & $\begin{array}{c}\text { Value } \\
{[\mathbf{U S} \$ \mathbf{]}}\end{array}$ \\
\hline January & 30,150 & 229,040 & 778.4 & $202,605.00$ \\
\hline February & 29,120 & 381,360 & 795.2 & $226,722.00$ \\
\hline March & 37,520 & 473,200 & 1,092 & $282,279.00$ \\
\hline April & 38,080 & 533,680 & 1,092 & $328,336.00$ \\
\hline May & 28,560 & 412,160 & 980 & $250,516.00$ \\
\hline June & 28,560 & 332,640 & 940 & $219,246.00$ \\
\hline July & 33,040 & 145,600 & 845 & $231,076.00$ \\
\hline August & 33,852 & 301,856 & 840 & $215,114.00$ \\
\hline September & 34,126 & 281,820 & 711 & $205,004.00$ \\
\hline October & 33,264 & 259,840 & 683 & $193,680.00$ \\
\hline November & 27,294 & 210,879 & 694 & $148,916.00$ \\
\hline December & 27,535 & 225,764 & 694 & $157,698.00$ \\
\hline & Summation & Summation & Media & Summation \\
\hline Total & 381101 & 3787839 & 857.1 & 2.662 .192 .00 \\
\hline
\end{tabular}

\section{A. System of Co-generation}

In order to meet the energy demand, Fig. 1 shows the proposed system of co-generation and thermal power plant. The system consists of a boiler for burning rice husk and for producing superheated steam. The effective pressure steam is extracted from the turbine and the rest of the steam leaves the turbine at low pressure, reaching the condenser. The condensate is then connected to the main tank, along with water to compensate for losses. The mixture is then pumped from the tank to the main boiler, closing the thermal cycle [1].

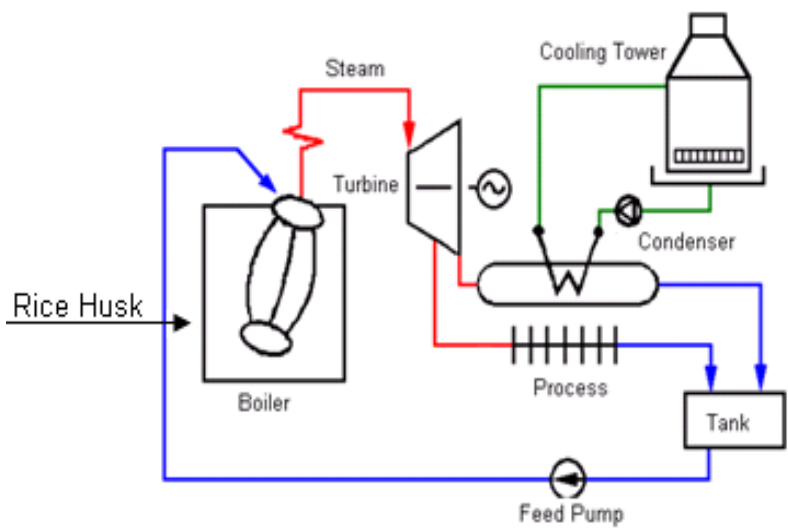

Fig. 1. System Co-generation of electrical energy.

\section{B. Dimensioned of Boiler, Turbine and Power Generator}

Currently there are numerous alternatives for commercial items related to the boiler, turbine and electric generator. However for increased efficiency, there is the conventional fluidized bed furnace. This fuel is burned in a bed height set within which typically arise bundles of tubes to control the combustion temperature, thus avoiding the merging of rice husk ash [1].

In this study, we opted for water tubular boiler (Fig. 2), capable of super-heated steam producer 42 $\mathrm{kgf} / \mathrm{cm}^{2} / 420{ }^{\circ} \mathrm{C}$, showing a peak of $15 \mathrm{t} / \mathrm{h}$ steam and $88 \%$ efficiency, using rice husk as fuel. The return water from the process has temperature of $120^{\circ} \mathrm{C}$. It is known that $13.5 \mathrm{t} / \mathrm{h}$ of steam will be consumed by the MPS. To meet the demand necessary the amount of steam $3.1 \mathrm{t} / \mathrm{h}$ about rice husk.

In selecting the turbine it was taken into account its steam consumption, pressure and temperature. The turbine for this project has the following features as listed in Table II:

Table II. - Characteristics construct of turbine

\begin{tabular}{|c|c|}
\hline Construct Parameters & Characteristic \\
\hline Power Generator & $1,200 \mathrm{KW}$ \\
\hline Input Pressure & $42 \mathrm{Bar}$ \\
\hline Input Temperature & $420^{\circ} \mathrm{C}$ \\
\hline Input Flow & $13,500 \mathrm{~kg} / \mathrm{h}$ \\
\hline Pressure Extraction & $10.6 \mathrm{Bar}$ \\
\hline Extraction Flow & 8,000 \\
\hline Pressure Escape & 1.05 \\
\hline Flow Escape & $5,500 \mathrm{~kg} / \mathrm{h}$ \\
\hline Efficiency & $29.8 \%$ \\
\hline
\end{tabular}




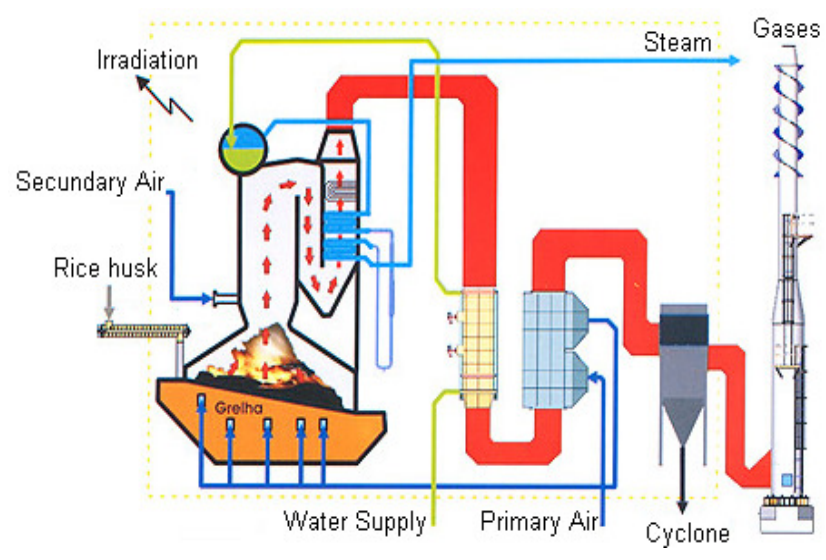

Fig. 2. Boiler of fluidized bed.

The generator characteristics specified in this case study was $1,200 \mathrm{~kW}$ and $13,800 \mathrm{~V}$ (operating voltage of the rice processing industry), a system of 4-pole synchronous generator, $60 \mathrm{~Hz}$ and 1,800 rpm with $96 \%$ efficiency.

\section{Estimated Costs of Operation and Maintenance}

Fixed costs include the maintenance of the power plant, estimated at $20 \mathrm{US} \$ / \mathrm{kW}$ [5]. In this case, the amount disbursed to the MPS fixed cost will be approximately US\$ 96,960 per year.

Variable costs are expenses related to manpower, and are usually estimated at US $\$ 0.0023 / \mathrm{kWh}$ [5]. Thus, for this study the amount disbursed to cost of MPS variables were approximately US\$ 89,202.2 per year.

\section{Analysis and Results Discussion}

The economic analysis here implemented is functional of the estimate of expenditure involved in the initial investment for construction, operation and maintenance, fuel costs and revenue generated during a given period of time. This analysis allows assembling the cash flow on these investments, costs and revenues to determine which are the economic indicators as well as more investment alternatives.

It is considered that the rice processing industry, through the implementation of an MPS can operate 24 hours a day, 346 days a year, totaling 8,300 hours of operation. The main objective is to provide the industry to ensure the supply of electricity it needs. This system of operation will consume 25,730 tons of bark per year, with a utilization factor of 0.94 , greater than conventional thermoelectric plants that use coal, natural gas or diesel whose is utilization factor varies from 0.3 to 0.7 [6].

During one year of operation, the MPS will produce 9,960 MWh, and this total will be 5,200 MWh consumed by industry and surplus (4,760 MWh) will be marketed.

\section{A. Costs of Investment}

The project cost of power generation can be broken down into direct (land, civil works, equipment, installation and substation) and indirect costs (site, camp and administration). According to [7], approximately $70 \%$ of the investment value in conventional steam plants is direct costs, which have the composition shown in Table III.
Table III. - Typical composition of direct investment costs of a power station steam rice industry.

\begin{tabular}{|c|c|}
\hline Item Considered & Participation Cost \\
\hline Project & US\$ $300,000.00$ \\
\hline $\begin{array}{c}\text { Design of boiler } \\
\text { Design of turbine and power } \\
\text { generator }\end{array}$ & US\$ $4,800,000.00$ \\
\hline Tubing and accessories & US $\$ 300,200,000.00$ \\
\hline Auxiliary equipments & US\$ 500,000.00 00 \\
\hline Installation of equipments & US\$ $1,000,000.00$ \\
\hline Construction & US\$ $1,000,000.00$ \\
\hline Modification in Production & US\$ 1,600,000.00 \\
\hline Total & US\$ 12,700,000.00 \\
\hline
\end{tabular}

The results from this venture will be generated by three different sources (Table IV). The first source of revenue comes from the resources that will no longer be spent on the purchase of electricity. The second source is revenue from the sale of surplus electricity, with approximately US\$ 36.90/MWh. In another option, the energy produced can be sold directly to retailers, free consumers or dealers, through bilateral contracts, or offered at auction. The third and final source of revenues is earned from sale of carbon credits generated by the project, whose value in the international market ranges between US\$ 5.00 and US\$ 10.00 per ton of carbon equivalent (tCO 2 eq). In this case will be considered an average value of US\$ 7.00 / tCO2eq.

Table IV. - Frame of Source

\begin{tabular}{|l|c|c|c|}
\hline \multicolumn{1}{|c|}{ Source } & Quantity & Unit Cost [US\$] & Total [US\$] \\
\hline $\begin{array}{l}\text { 1.Energy that will be } \\
\text { acquired [MWh] }\end{array}$ & - - - & - - & $2,662,192.00$ \\
\hline $\begin{array}{l}\text { 2._Excess power } \\
\text { commercialized } \\
\text { [MWh] }\end{array}$ & $4,760.00$ & 131.06 & $623,845.60$ \\
\hline $\begin{array}{l}\text { 3. Carbon credits } \\
\text { commercialized } \\
{\left[\mathrm{tCO}_{2} \text { eq] }\right.}\end{array}$ & $21,112.34$ & 28.28 & $587,056.96$ \\
\hline \multicolumn{1}{|c|}{ Total [US\$] } & $\ldots$ & $\ldots-$ & $\mathbf{3 , 8 8 3 , 0 9 5 . 5 6}$ \\
\hline
\end{tabular}

\section{B. Environmental Benefits}

The project cost of power generation can be broken down into direct costs (land, civil works, implementation of MCT in two different ways contribute to the mitigation of greenhouse gases, which are calculated based on the methods ID - Grid connected renewable electricity generation and III.E - Avoidance of methane production from biomass decay through controlled combustion [8]. One way is through the replacement of 9,960 MWh of electricity distribution network, which is partly generated from fossil fuels (coal and natural gas). This replacement of fossil fuels, cut around $0.463 \mathrm{tCO} 2 \mathrm{eq} / \mathrm{MWh}$ of energy produced, resulting in a decrease in emissions of greenhouse gases tCO2eq/year of 4,611.48.

The other form of order comes from the reduction of emission of methane from the decomposition of 6,590 tons/ year of rice husk that would be deposited in the soil. 
It is known that methane has a greenhouse power of 21 times that of carbon dioxide resulting in a total emission of methane 16,500.86 tCO2eq/year.

\section{Economic Analysis}

Based on the cash flow of the project, various economic and financial analysis can be developed in order to quantify its attractiveness for those who make the investment. Accordingly, this paper presents the indicators used in the economic evaluation of the project, which were calculated to model the time return on investment (Payback) and the Uniform Annual Equivalent Value (vaue). The Minimum Rate of Appeal (EBA) is the rate from which the investor believes that getting financial gain. It is a fee associated with a low risk, i.e., any leftover cash can be applied, at worst, in the TMA. The time for return on investment or payback, compares the costs and income determines the amount of time required to recover the initial investment. A payback period is calculated taking into account the current value of money, using the TMA rate (minimum rate of attractiveness). On the other hand, the method of the Uniform Annual Equivalent Value (vaue) consists of finding a uniform series equivalent annual cash flow of investments to the TMA, or thinking the series is uniformly equivalent to all costs and revenues for the project using the TMA [9].

For the analysis of cash flow through investment, we use two cases: Case 1 with the sale of carbon credits; Case 2 not counting the profits from the sale of carbon credits, and considering the 5\% TMA and an equipment useful life for 20 years.

The time of return on investment through Payback, or return on invested capital, is one of the simplest indicators of investment that considers the time at which the project will pay the initial investment. As shown in Fig. 3, the return on investment will be 3.86 years for Case 1 , and 4.7 years for Case 2. It can be observed that even without the sale of carbon credits (Case 2), the project is presented as an attractive investment.

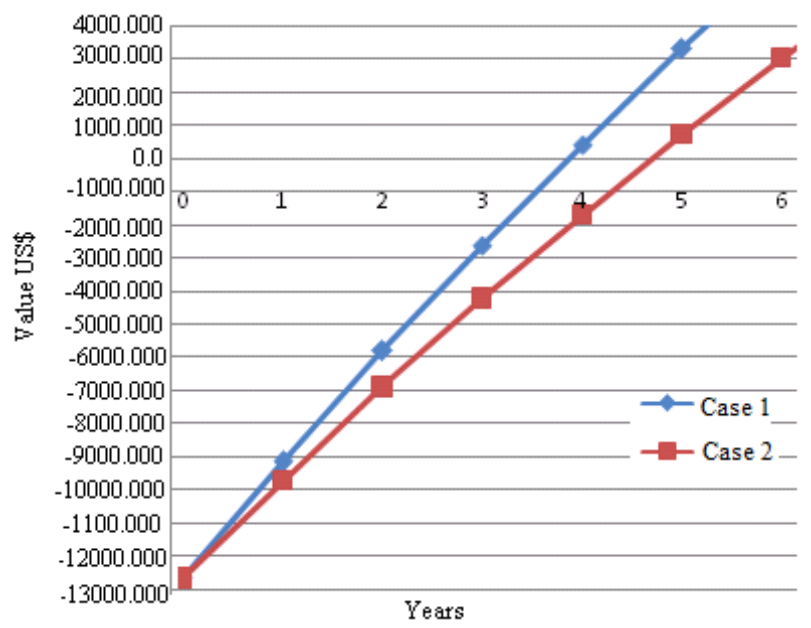

Fig. 3. Time of return on investment.

Through analysis of the value, it is known exactly how much each case study can yield uniformly per year in the life of the project. If the investment yields a uniformly US\$ 4,913,947.48 per year, Case 2 will yield US\$
2,080,794.54. By the criteria value, Case 1 shows a very attractive investment, as in Case 2 showing lower returns even more economically viable.

\section{Main Conclusions}

Based on the analysis presented in this paper the biomass should be a priority, given the proven environmental benefits, and a substantial financial return, especially with the investment obtained from the sale of carbon credits.

The use of rice husk as a source of electric power can provide substantial savings to the cooperatives of rice. Its viability is fundamentally linked to the ability to internalize the environmental benefits provided by it, as the benefits obtained through the sale of carbon credits. The investment project studied for this sector allows savings in power, since this type of spending is a significant cash outflow. Thus, saving the consumer pays less, reflecting future cash inflows. The results analysis of both methods showed that the proposed investment to install MPS is an economically viability, even without input of carbon credits.

\section{References}

[1] R. Pretz, Potencial bioenergético do setor arrozeiro do rio Grande do Sul: uma abordagem termelétrica, Tese de Doutorado, PROMEC/UFRGS, Porto Alegre, Brasil, 2001.

[2] NOGUEIRA, Luiz Augusto Horta. Energia: Conceitos e Fundamentos. Conservação de Energia eficiência energética de instalações e equipamentos. Itajubá: Editora da EFEI, 2001.

[3] R. Hoffmann, 1999. Método Avaliativo da Geração Regionalizada de Energia, em potências inferiores a $1 \mathrm{MW}$ a partir da gestão de resíduos de Biomassa - O caso da Casca de Arroz. Doutorado, PROMEC-UFRGS, Porto Alegre, RS.

[4] E. S. Lora; J. F. Happ, "Classificação e Balanço Térmico das Fornalhas para Combustão de Biomassa". Manaus: Universidade do Amazonas, 1997.

[5] R. Bain; K. Craig; K. Comer, Renewable Energy Technology Characterizations. Washington: California, 1997.

[6] S. T. Coelho; C. E. M. Paletta; M. A. V. Freitas. Medidas mitigadoras para a redução de emissõesde gases de efeito estufa na geração termelétrica, Brasília, 2000.

[7] E. E. S. Lora; M. A. R. Nascimento, Geração Termelétrica -Planejamento, Projeto, Operação.Rio de Janeiro: Editora Interciência, 2004.

[8] UNFCCC -United Nations Framework Convention on Climate Change, 2007.

[9] N. F. Casaroto; B. H. Kopittke. Análise de Investimento. Matemática Financeira. Engenharia Econômica. Tomada de Decisão. Estratégia Empresarial. São Paulo: Editora Atlas, 2000. 